\title{
Data analysis of the flue gas emissions in the thermal-power plant firing fuel oil and natural gas
}

\author{
B. Nakomcic-Smaragdakis $\cdot$ Z. Cepic $\cdot$ \\ M. Cepic • T. Stajic
}

Received: 19 October 2011/Revised: 3 April 2012/ Accepted: 12 February 2013/Published online: 14 November 2013

(C) Islamic Azad University (IAU) 2013

\begin{abstract}
The thermal-power plant with combined heat and power (CHP) production located in the city of Zrenjanin (Serbia) is powered by two steam boilers with nominal power of $280 \mathrm{MW}$ each. Considering the problem of increasing pollutant emissions that occur during fossil-fuel combustion process, which is recognized as an arising problem in the CHP Zrenjanin, the accredited Laboratory has been carrying out monitoring and control of the emission production. The emissions have been measured during winter season on boiler B1 for five working regimes of burners, by adjusting the fuel ratio between natural gas and fuel oil. The measurement has been done regarding carbon monoxide, sulphur dioxide, nitrogen oxides (NOx), particulate matter (PM), gaseous inorganic chlorine compounds denoted as hydrogen chloride, and gaseous inorganic fluoride compounds denoted as hydrogen fluoride. Data acquired from those measurements have shown that all parameters except NOx and PM did not exceed emission limits defined under current regulatory statute. According to data analysis of the flue gas emissions, first preventive actions are recommended, then possible actions that could be taken during combustion process, and as last but not least, actions that have to be applied in case when emission problems appears. Regarding CHP control and management problems, some advices are given
\end{abstract}

B. Nakomcic-Smaragdakis $(\bowtie) \cdot$ Z. Cepic $\cdot$ T. Stajic

Faculty of Technical Sciences, Department of Environmental Engineering and Occupational Safety and Health, University of Novi Sad, Trg D. Obradovica 6, 21000 Novi Sad, Serbia e-mail: nakomcic@uns.ac.rs

M. Cepic

PD Panonske TE-TO Novi Sad, TE-TO Zrenjanin,

Beogradski put bb, 23000 Zrenjanin, Serbia emphasizing an integral approach to the analysis and optimization of the CHP as the best solution.

Keywords Emission measurements - Combined heat and power $\cdot$ Flue gas $\cdot$ Data analysis $\cdot$ Recommendation

\section{Introduction}

The main goal of every society is a rational energy management that could be achieved by increasing the energy efficiency of the existing plants, and/or by an optimal design of a new plants based on fossil-fuel utilization, and with involving renewable energy sources into energy balance of the society, with full respect of the energy, economy and environmental principles of the sustainable development. In Serbia, as well as in the rest of the Western Balkan countries, there is no significant experience in using an integral approach to the analysis and optimization of the energy systems that are taking into account energy, economy and environmental aspects (Nakomcic 2008).

Today, about $90 \%$ of the total energy output worldwide is from the combustion of fossil fuels (Fang et al. 2010; Kaewboonsonga et al. 2006; Xu et al. 2005). It is generally accepted that fossil fuels will remain the dominant primary energy source in the decades to come, with an increase in share for natural gas, the lowest fossil-fuel greenhouse gas emitter (Bogdan et al. 2007).

Combined heat and power (CHP) production, also known as cogeneration, represents one of the best ways for efficient use of energy (Bogdan and Kopjar 2006; Li et al. 2010). Combined heat and power systems are effective in reducing the primary energy consumption with respect to the conventional separate production of heat (produced in 
boilers) and electricity (produced in power plants) (Chicco and Mancarella 2008). The significant improvement in heat efficiency obtained by using CHP plants means lower fuel consumption and reduced flue gas emissions compared with separate generation of heat and power (Bogdan and Kopjar 2006; Li et al. 2010).

It is important to mention that CHP Zrenjanin, by decision taken from the Electric Power Industry of Serbia (EPIS), where CHP belongs, is chosen to be the plant that covers the peaks in electricity consumptions. Even CHP Zrenjanin was designed for electricity and heat production with a purpose to supply also industry and district heating system with necessary technology steam; since most of the industry was not operational during last 20 years and CHP is using fuel oil and natural gas as fuels that are expensive, it is hard to justify decision taken by EPIS from the energy and/or economy point of view (Borelli and Oliveira 2008; Spakovsky and Frangopoulos 1993; Tsatsaronis and Winhold 1984). A key issue in management of the fossil-fuel power generation is to secure highefficiency and environmentally friendly operation of thermal-power plants. Optimal distribution of the load demand among distinct units, or optimal load dispatch, is one of the proven options to minimize operating (or fuel) costs and/or environmental impacts (or emissions) of a power plant (co-)fired with fossil fuel(s) (Kuprianova et al. 2008).

Air pollution is the presence of air contaminants in the atmosphere, in concentrations larger than naturally occurred. Pollution from stationary combustion sources can contribute to formation of photochemical smog, acid rain and disrupt the atmospheric heat balance causing the greenhouse effect. Photochemical smog is a result of the photo-induced reaction of hydrocarbons (or volatile organic compounds (VOCs)) and nitrogen oxides (NOx). Causative agents in acid rain formation are typically associated with sulphur dioxide $\left(\mathrm{SO}_{2}\right)$ emissions and nitrogen oxide emissions, along with gaseous hydrogen chloride. Another global issue is the influence of air pollution on atmospheric heat balances and associated absorption or reflection of incoming solar radiation (Wang et al. 2005; Vallero 2008).

Most of research works have been addressed to NOx and $\mathrm{SO}_{2}$ as the major gaseous emissions included in various economic/environmental dispatch models; however, in some recent publications, contributions of other emissions [e.g. carbon dioxide $\left(\mathrm{CO}_{2}\right)$ and sulphur trioxide $\left(\mathrm{SO}_{3}\right)$ ] to environmental impacts by thermal-power plants have been considered as well (Kuprianova et al. 2008).

Knowledge of the types of pollutants and their emission rates is fundamental to the study and control of air pollution (Elbir et al. 2000). Since gaseous fuels like natural gas, methane or hydrogen are more environmentally friendly, switching from oil to gas or using their combination will reduce the pollutant emissions conforming them to the ecological norms in force and minimizing plant emission costs (Schneider and Bogdan 2007).

As revealed by experimental data obtained on utility boilers firing fuel oil and natural gas, $\mathrm{NOx}$ and $\mathrm{SO}_{3}$ formations are strongly influenced by combustion conditions in the boiler furnace (temperature and oxygen $\left(\mathrm{O}_{2}\right)$ concentration at the post-flame region, both following changes in the unit load), while $\mathrm{SO}_{2}$ and $\mathrm{CO}_{2}$ emission concentrations (corrected to reference excess air) are almost independent on the boiler load and air supply (Kaewboonsonga et al. 2006). Furthermore, with variation in unit loading, the thermal efficiency of a boiler may deviate from the rated value to some extent, affecting the fuel consumption by the boiler and, consequently, the emission rate of the gaseous pollutants (Kuprianov and Kaewboonsong 2004).

Besides the demand for increased efficiency of combustion units, it is also required that the emissions (England et al. 2001) of pollutants are minimized. The latter demand leads, namely in the power production sector, to a growing preference of cleaner fuels and extensive retrofits of existing technologies. In some cases, the so-called combined burners firing both liquid and gaseous fuels are applied. The reasons for the application of such burners may be economical (fuel costs' optimization) or the gas fuel supports the combustion of low-calorific liquid waste (Kermes et al. 2008).

However, there is a lack of studies for determining the emission characteristics for a boiler co-fired with different fuels (Kaewboonsonga et al. 2006).

The main objective of this paper is data analysis of the flue gas emissions from a boiler co-fired fuel oil and natural gas, as well as recommendation of actions that has to be taken according to the real situation in CHP regarding to emission measurements. Also, there is an intention to emphasize weaknesses and consequences of a bad decision taken regarding energy system management that could be characterized rather by partial than an integral and overall approach to the energy systems problems (Ahern 1980; Azzarone and Sciubba 1995; Lin and Tsatsaronis 1993). As a solution for the energy systems as complex systems (Taubman 1983), the integral approach (Frangopoulos 1990; Hossain et al. 2010) could be used for forming national, regional and local energy, economy and environmental strategy for energy systemrelated problems. As an additional, but not less important aspect, it should be mentioned that in the field of energy 
Table 1 Characteristics of fuel oil in reservoirs in the CHP Zrenjanin (Bio-Ecological Centre 2008)

\begin{tabular}{llccc}
\hline Characteristic & Unit & \multicolumn{2}{l}{ Results obtained on date } & $\begin{array}{l}\text { Methods according to the } \\
\text { Serbian standards }\end{array}$ \\
\cline { 3 - 5 } & & 19.12 .2007 & 19.02 .2008 & SRPS EN ISO 3675 \\
\hline Density $\left(15^{\circ} \mathrm{C}\right)$ & $\mathrm{kg} / \mathrm{m}^{3}$ & 952.8 & 966.1 & SRPS ISO 3104 \\
Viscosity $\left(100^{\circ} \mathrm{C}\right)$ & $\mathrm{mm} / \mathrm{s}^{2}$ & 27.63 & 32.70 & SRPS ISO 8754 \\
Sulphur content & $\%(\mathrm{~m} / \mathrm{m})$ & 1.06 & 1.94 & SRPS EN ISO 3675 \\
Flash Point & ${ }^{\circ} \mathrm{C}$ & 210 & 40.69 & ASTM D 1551 \\
Heating value & $\mathrm{MJ} / \mathrm{kg}$ & 41.14 & 9 & SRPS ISO 3016 \\
Pour point & ${ }^{\circ} \mathrm{C}$ & 10 & 0.0 & SRPS B.H8. 150 \\
Water and sediment content & $\%(\mathrm{v} / \mathrm{v})$ & 0.0 &
\end{tabular}

systems, it is very important to have an effective inspection programme and maintenance plan that will be based on risk assessment analysis and implement in Serbian industry, as well as, in energy sector (Nakomcic et al. 2006).

The paper presents the first above-mentioned case, where we already have an existing thermal-power plant operating in certain technical and economical conditions facing the problem regarding to the flue gas emissions that was registered by the inspection body. The thermal-power plant located in the city of Zrenjanin (Serbia) is powered by two steam boilers B1 and B2 with a single nominal power of $280 \mathrm{MW}$. Each boiler contains eight burners that allow simultaneous combustion of fuels, fuel oil and natural gas.

Air quality problems from industrial sources mainly concern areas with thermo-electrical power stations and industrial units located close to residential areas (Dimitroulopoulou et al. 2011). Air pollution sources such as CHP emits both gaseous and particulate matter into the ambient air. An air pollution problem involves three parts: the pollution source, the movement or dispersion of the pollutant, and the recipient. The presence of air pollutants in the atmosphere results in formation of photochemical smog, acid rain, and global warming (Nazari et al. 2010). Reduction in the emissions in CHP Zrenjanin has particular contribution in solving the global problem with greenhouse gas (GHG) emission, and since Serbia has signed Kyoto Protocol in 2007 (Kyoto Protocol, 1998), it became obligatory for her. At the same time, it gives a chance to Serbia for using Kyoto Protocol mechanisms and EU funds for emission reductions. Due to Kyoto agreement and apart from the demands for GHG reduction, Republic of Serbia will face even more stricter regulations considering pollutant emissions when became candidate country for EU (European Commission 2011).
The aim of the paper is data analysis of flue gas emission from CHP fired fuel oil and natural gas, as well as recommendation of actions that has to be taken according to the real situation in CHP from the emission problem point of view.

\section{Materials and methods}

Thermal-power plant is located in the industrial area of the city of Zrenjanin, near the main road Zrenjanin-Belgrade, producing the electricity and supplying the city with technology steam needed for district heating and industry. Production capacity of CHP regarding technology steam is $220 \mathrm{t} / \mathrm{h}$, installed heat energy $140 \mathrm{MW}_{\mathrm{th}}$ and installed electricity is $120 \mathrm{MW}_{\mathrm{e}}$.

This CHP has typical technology scheme consisting of two steam boilers, one condensing steam turbine with extractions, three heat exchangers, chemical water treatment facility, two fuel oil tanks with capacity $10.000 \mathrm{t}$ each and head quarter.

Within the plant, there are two steam boilers (B1 and B2), with same characteristics, using fuel oil and natural gas simultaneously for combustion process. Total heat power of the boiler room is $560 \mathrm{MW}(2 \times 280 \mathrm{MW})$. Installed capacity of each boiler is $330 \mathrm{t} / \mathrm{h}$, with working pressure of 117 bar. Each boiler has eight combined burners, individual power of $35 \mathrm{MW}$ (Bio-Ecological Centre 2008).

Fuel switch between fuel oil and natural gas is possible even during minimal operating regime of the boilers. Simultaneously, combustion of the both of types of the fuels is possible by combining the burners. Within the CHP, there is no emission reduction equipment installed.

Accredited Laboratory has conducted monitoring and control of the emission production. The experiment was carried out during winter season 2007-2008 with sampling 
and measuring provided on boiler B1 for five working regimes of burners, by adjusting the fuel ratio between natural gas and fuel oil. The measuring has been done according to the recommended standards for each pollutant, emphasizing the monitoring of following parameters: particulate matter (PM), carbon monoxide (CO), $\mathrm{SO}_{2}$, $\mathrm{NOx}$, gaseous inorganic compounds of chlorine $(\mathrm{HCl})$ and gaseous inorganic compounds of fluoride (HF).

\section{Measurements conditions}

Within furnace, fuel combustion process is occurring under following working conditions: the pressure is $32 \mathrm{mbar}$, theoretical temperature is around $2,000{ }^{\circ} \mathrm{C}$, and the temperature of combustion air is in a range from 260 to $270{ }^{\circ} \mathrm{C}$ depending of a boiler load.

During measuring of the harmful and hazardous matter emissions on the boiler "B1", two types of fuels have been used and their characteristics are presented in Tables 1 and 2.

\section{Experimental regime}

The concentration level of harmful and hazardous matter emissions in the area of pollution sources is determined by emission measuring. During in situ sampling of the flue gasses, samples are drawn out through the sampling nozzles. According to the "Regulation on emission's limiting values, methods and terms of data measuring and tracking" (Official Gazette of the Republic of Serbia, No 30/97 and 35/97 1997), hereinafter called "the Regulation act", following pollutants have to be monitored:

- Particulate matter (PM), (ISO 9096:2003; ISO 12141:2004),

- Carbon monoxide (CO), (EN 50379-1:2004; EN 50379-2:2004 EN 50379-3:2004; US EPA; CTM 030; US EPA:CTM 034),

- Sulphur oxides denoted as $\mathrm{SO}_{2}$,

- Nitrogen oxides (NOx),

- Gaseous inorganic fluoride compounds denoted as hydrogen fluoride (HF), (ISO 15713:2006; US EPA Method 13a),

- Gaseous inorganic chlorine compounds denoted as hydrogen chloride $(\mathrm{HCl})$, (EN 1911-1,2 and 3:1999; US EPA Method 26; US EPA Method 0050; US EPA Method 0051).

According to above-mentioned Regulation act issue for furnaces operating on liquid and gaseous fuels, the oxygen content in flue gas volume is $3 \%$. Measured emission concentrations and ELVs are given in the form of mass 
concentration (mass of matters emitted per volume unit, $\mathrm{mg} / \mathrm{m}^{3}$ ), in dry flue gas on temperature of $0^{\circ} \mathrm{C}$ and under pressure of 1013 mbar (Official Gazette of the Republic of Serbia, No 30/97 and 35/97, 1997).

By order of the Inspection for Environmental Protection, the emission control measurement has been conducted in the CHP Zrenjanin. Accredited Laboratory has carried out experiment under proposed experiment regimes when boiler B1 was operating, as follows:

1. Emissions measuring when all 8 burners operate on fuel oil (8FO-0NG);

2. Emissions measuring when 6 burners operate on fuel oil and 2 operate on natural gas (6FO-2NG);

3. Emissions measuring when 4 burners operate on fuel oil and 4 operate on natural gas (4FO-4NG);

4. Emissions measuring when 2 burners operate on fuel oil and 6 operate on natural gas (2FO-6NG);

5. Emissions measuring when all 8 burners operate on natural gas (0FO-8NG).

It should be noticed that the first two experiment regimes (1. and 2.) were carried out during one working day in December 2007, and all others regimes such as 3-5 were undertaken during two working days in February 2008.

\section{Measuring point location}

A concrete stack, height of $160 \mathrm{~m}$, is a flue gas emitter. This stack is used by both boilers, which are connected through two flue gasses ducts. Sampling has been carried out in the flue gasses duct that connects boiler B1 and stack. The cross-sectional surface of flue gasses duct is $4.5 \times 2.7 \mathrm{~m}^{2}$ and at the same time represents the size of a sampling plane. Four sampling lines with four intake nozzles are installed in the sampling plane, parallel to each other. Distance from the sampling plane to a duct curve is $7 \mathrm{~m}$, and straight part of the duct, from sampling plane to stack, is $18 \mathrm{~m}$. Access to the sampling point is from sampling platform.

The scheme of the boiler room with flue gasses ducts along with the position of ports for sampling is given in Fig. 1, and measuring point location on the spot is shown in Fig. 2.

Sampling and analysis procedures with measuring equipment description

Standard procedures and methods were applied for the sampling, measuring and analysis of the pollutant emissions according to the legislative and regulative (Law on

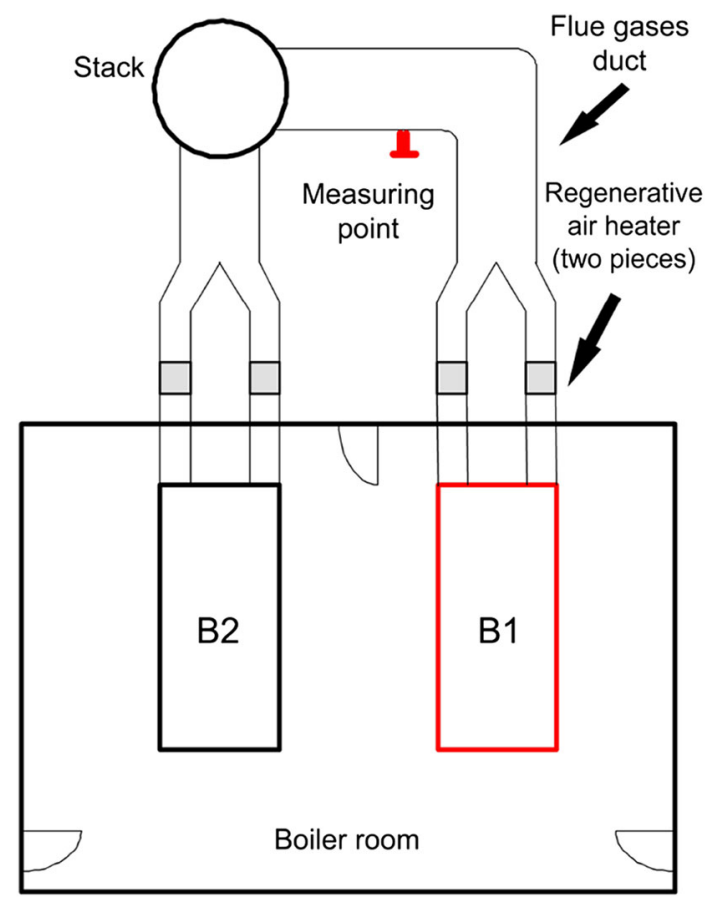

Fig. 1 The scheme of the boiler room and flue gasses ducts

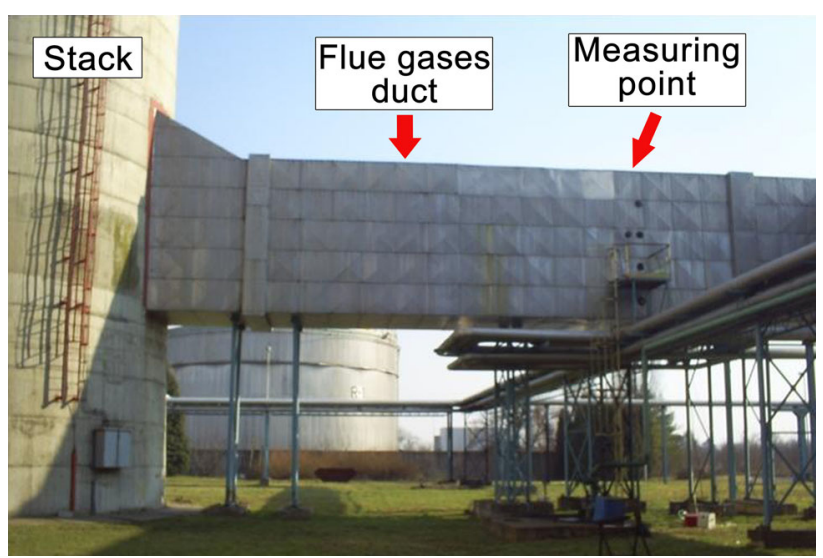

Fig. 2 Measuring point location

environmental protection (Official Gazette of the Republic of Serbia, No 135/04 2004) and the Regulation act of the Republic of Serbia (Official Gazette of the Republic of Serbia, No 30/97 and 35/97 1997)). Sampling and measuring of the harmful and hazardous matters are done at the pollution source with standardized measuring equipment.

The collection of gas pollutant samples $\left(\mathrm{CO}, \mathrm{SO}_{2}, \mathrm{NO}\right.$ and $\mathrm{NO}_{2}$ ) was taken by automatic gas analyser TESTO350XL (Testo Inc. 2006). Gas pollutant concentration measuring was performed with electrochemical sensors, and flue gas temperature was determined by $\mathrm{NiCr}-\mathrm{Ni}$ thermo-element. 
Preliminary flue gas flow measuring was conducted with Pitot "S" tube and sensors for differential and static pressure, just before sampling particulate matter (PM).

Sampling procedure was carried out under isokinetic conditions using the Tecora "Isostack Basic" device (Envirolab 2006), by filtrating flue gasses through the fibber-glass filter. Measurement point was located at the horizontal part of harmful and hazardous matter emitter, at the flue gasses duct. Particulate matter mass concentration in emitter is determined by gravimetric method.

Hydrogen fluoride and hydrogen chloride samples were taken by four-channel's sampling device "PRO-EKOS" Belgrade, type AT-801X2 (Pro-Ekos doo 2006). Gaseous inorganic fluoride compounds denoted as HF in flue gasses were determined by spectrophotometric method. Sample analysis was performed by UV/VIS Spectrophotometer HP model 8452A (Hewlett Packard 2006). Concentrations of gaseous inorganic chlorine compounds denoted as $\mathrm{HCl}$ in flue gas sample were determined according to titrimetric method.

\section{Results and discussion}

Considering the problems with pollutant emissions from $\mathrm{CHP}$, and according to the Regulation act, the following pollutants $\mathrm{SO}_{2}, \mathrm{NOx}, \mathrm{HCl}, \mathrm{PM}, \mathrm{CO}$ and $\mathrm{HF}$ were monitored, measured and controlled (Bio-Ecological Centre 2008).

Measurements are set up according to the real needs of CHP; it means, CHP did not have an intention to provide a wide range of possibilities for emission reduction, but rather to finds the solutions that could be reachable for them, taking into account technical and economical reality and environmental constrains. Monitoring and measurement of the flue gas pollutant concentration was performed for the most common daily boiler load (range from 80 to $90 \%)$.

Measurement results for $\mathrm{CO}, \mathrm{HF}$ and $\mathrm{HCl}$ are represented in Tables 3, 4 and 5, and Figs. 3, 4 and 5, respectively, represent $\mathrm{SO}_{2}, \mathrm{PM}$, NOx. The reason for table representative form of $\mathrm{CO}$ and $\mathrm{HF}$ concentration data comes from the fact that emissions are below measurable level that cause the graphic form representation to be unusable. The results of $\mathrm{HCl}$ measurement data are shown in the Table 5.

A boiler should always be supplied with more combustion air than is theoretically required, in order to ensure complete combustion and safe operation. If the air rate is too low, there will be a rapid build-up of carbon monoxide in the flue gas and, in extreme cases, smoke will be produced (i.e. unburned carbon particles) (Ozdemir 2004). At the same time, boiler efficiency is very dependent on the

Table 3 Measurement results for CO concentration in flue gas (Bio-Ecological Centre 2008)

\begin{tabular}{llllll}
\hline Regime & Unit & \multicolumn{2}{l}{ Boiler load (\%) } & & \\
\cline { 3 - 6 } & & 83 & 86 & 89 & \\
\hline 8FO-0NG & $\mathrm{mg} / \mathrm{Nm}^{3}$ & $\mathrm{nd}^{\mathrm{a}}$ & $\mathrm{nd}^{\mathrm{a}}$ & $\mathrm{nd}^{\mathrm{a}}$ & 175 \\
6FO-2NG & $\mathrm{mg} / \mathrm{Nm}^{3}$ & 1 & $\mathrm{nd}^{\mathrm{a}}$ & $\mathrm{nd}^{\mathrm{a}}$ & 175 \\
$4 \mathrm{FO}-4 \mathrm{NG}$ & $\mathrm{mg} / \mathrm{Nm}^{3}$ & $\mathrm{nd}^{\mathrm{a}}$ & $\mathrm{nd}^{\mathrm{a}}$ & $\mathrm{nd}^{\mathrm{a}}$ & 175 \\
2FO-6NG & $\mathrm{mg} / \mathrm{Nm}^{3}$ & $\mathrm{nd}^{\mathrm{a}}$ & $\mathrm{nd}^{\mathrm{a}}$ & $\mathrm{nd}^{\mathrm{a}}$ & 100 \\
0FO-8NG & $\mathrm{mg} / \mathrm{Nm}^{3}$ & $\mathrm{nd}^{\mathrm{a}}$ & $\mathrm{nd}^{\mathrm{a}}$ & $\mathrm{nd}^{\mathrm{a}}$ & 100 \\
\hline
\end{tabular}

${ }^{a}$ Not detected

Table 4 Measurement results for HF concentration in flue gas (Bio-Ecological Centre 2008)

\begin{tabular}{|c|c|c|c|c|c|}
\hline \multirow[t]{2}{*}{ Regime } & \multirow[t]{2}{*}{ Unit } & \multicolumn{3}{|c|}{ Boiler load (\%) } & \multirow[t]{2}{*}{ ELV } \\
\hline & & 83 & 86 & 89 & \\
\hline $8 \mathrm{FO}-0 \mathrm{NG}$ & $\mathrm{mg} / \mathrm{Nm}^{3}$ & $<1$ & $<1$ & $<1$ & 5 \\
\hline 6FO-2NG & $\mathrm{mg} / \mathrm{Nm}^{3}$ & $<1$ & $<1$ & $<1$ & 5 \\
\hline $4 \mathrm{FO}-4 \mathrm{NG}$ & $\mathrm{mg} / \mathrm{Nm}^{3}$ & $<1$ & $<1$ & $<1$ & 5 \\
\hline $2 \mathrm{FO}-6 \mathrm{NG}$ & $\mathrm{mg} / \mathrm{Nm}^{3}$ & $<1$ & $<1$ & $<1$ & 5 \\
\hline 0FO-8NG & $\begin{array}{l}\text { Not measured (according } \\
\text { to the Regulation act) }\end{array}$ & & & & \\
\hline
\end{tabular}


Table 5 Measurement results for $\mathrm{HCl}$ concentration in flue gas (Bio-Ecological Centre 2008)

\begin{tabular}{lllll}
\hline Regime & Unit & \multicolumn{2}{l}{ Boiler load $(\%)$} & 89 \\
\cline { 2 - 5 } & & 83 & 86 & $<2.5$ \\
\hline 8FO-0NG & $\mathrm{mg} / \mathrm{Nm}^{3}$ & $<2.5$ & $<2.5$ & $<2.5$ \\
6FO-2NG & $\mathrm{mg} / \mathrm{Nm}^{3}$ & $<2.5$ & $<2.5$ & $2.60 \pm 0.24^{\mathrm{a}}$ \\
4FO-4NG & $\mathrm{mg} / \mathrm{Nm}^{3}$ & $2.60 \pm 0.24^{\mathrm{a}}$ & $<2.5$ & 30 \\
2FO-6NG & $\mathrm{mg} / \mathrm{Nm}^{3}$ & $13.34 \pm 1.24^{\mathrm{a}}$ & $10.00 \pm 0.93^{\mathrm{a}}$ & 30 \\
0FO-8NG & & Not measured (according to the Regulation act) & $30.00 \pm 0.93^{\mathrm{a}}$ \\
\hline
\end{tabular}

${ }^{a}$ Data are presented with expended measurement uncertainty

Fig. $3 \mathrm{SO}_{2}$ concentration in flue gas

Fig. 4 PM concentration in flue gas

Fig. 5 NOx concentration in flue gas
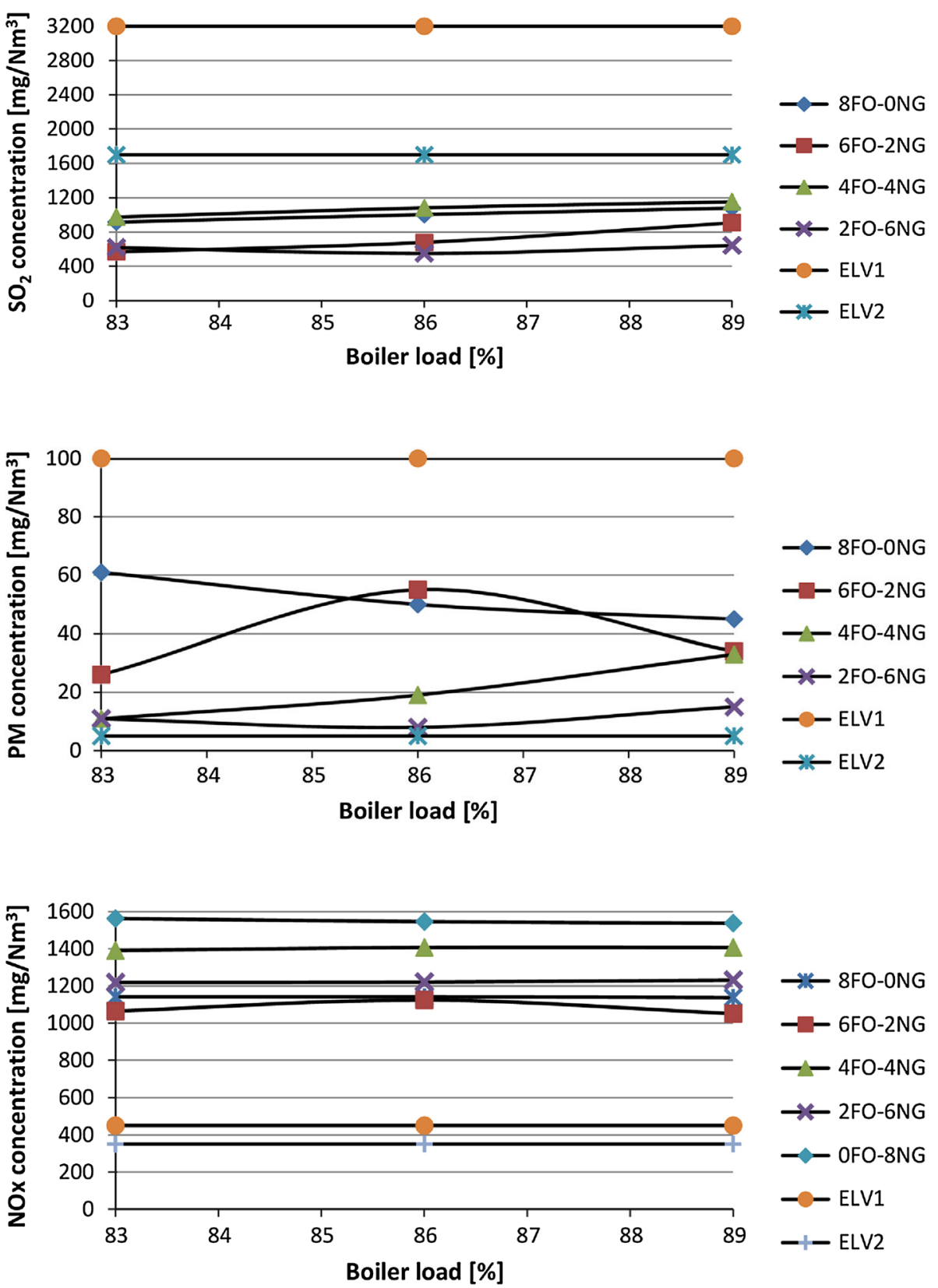
excess air rate. Excess air should be kept at the lowest practical level to reduce the quantity of unneeded air that is heated and exhausted at the stack temperature (Bahadori and Vuthaluru 2010).

Based on the results shown in Table 3, it could be seen that in every five experimental regime, $\mathrm{CO}$ concentration was under electrochemical sensor detection threshold limit, which is $1.25 \mathrm{mg} / \mathrm{Nm}^{3}$. It follows that, similar with the NOx case, the production of CO depends on the air excess coefficient value (Cardu and Baica 2005). According to variations in excess air coefficient, combustion process is operated in a way to keep formatted $\mathrm{CO}$ level at minimum, which ensures that fuel is completely utilized. According to $\mathrm{CO}$ measurements data, $\mathrm{CO}$ reduction is not necessary to be discussed, since $\mathrm{CO}$ level is acceptable.

In case when all of the eight burners are operating on natural gas, it is not necessary to measure HF concentration (see Table 4), which is declared by the Regulation act. The rest of four regimes have shown that HF concentrations were below level of quantified method $\left(\mathrm{HF}<1 \mathrm{mg} / \mathrm{Nm}^{3}\right)$. Above-mentioned comments prove well, what actually fundamental science states, that a presence of $\mathrm{HF}$ in the flue gas depends directly of fuel composition. The possible presence of HF in flue gas may mean that fuel oil was mixed with a small amount of residual oil (e.g. motor and/or turbine oil). Analysis of the HF measurements data shows that fuel oil that was utilized has no significant amounts of fluorine compounds. Because HF was not detected in the flue gas, there is no need for any action to be taken in order to decrease the HF emission level.

Considering the $\mathrm{HCl}$ measuring data (see Table 5), it could be seen that there are some inconsistency with the theoretical assumptions. The first inconsistency comes from the fact that in case of the regime 3, when fuel oil utilization amount is double than in case of regime $4, \mathrm{HCl}$ emissions were four times lower than it was expected according to the theory. It should also be mentioned that in regime 4 , measurements for 86 and $89 \%$ boiler load are the exactly the same, what is the least probable to happen in reality, and it request to reconsider the influence of possible measurement error on the measurement data. In regime 1 and 2 when fuel oil was dominant, $\mathrm{HCl}$ emissions were below the quantified method that could be explained by facts that different fuel oil was used than it was in the rest regimes (see Table 1). Since the $\mathrm{HCl}$ measurement data shows that $\mathrm{HCl}$ emissions are significantly below emission level value (ELV), there is no need to propose measures for emission reduction.
According to the above defined regimes from 1 to 3 , where fuel oil is dominant fuel, corresponding emissionlevel value is ELV1, and for regimes 4 and 5, where natural gas is dominant fuel, it is ELV2 (see Figs. 3, 4, 5).

In case when all of the eight burners were operated on natural gas, $\mathrm{SO}_{2}$ concentration was below electrochemical sensor detection limit as it was expected (Fig. 3).

For regimes 3 and 4, fuel oil that was used had $1.94 \%$ of sulphur content, and for regimes 1 and 2 had $1.06 \%$ sulphur content. In 3 and 4 regimes even if the number of burners operating on fuel oil was less, (i.e. less amount of fuel oil was burned), $\mathrm{SO}_{2}$ concentration level was increased because the sulphur content in the fuel oil was higher. Trend of reaching higher $\mathrm{SO}_{2}$ concentration level with increasing boiler load (Kuprianova et al. 2008) was also expected because more fuel oil is burned. Anyhow, in the first four regimes, $\mathrm{SO}_{2}$ concentration was significantly below emission limit value, and it does not need intervention for $\mathrm{SO}_{2}$ reduction.

When all eight burners are operating on natural gas, particulate matter concentration was below quantification method limit ( $\mathrm{PM}<0.5 \mathrm{mg} / \mathrm{Nm}^{3}$ ), (Fig. 4).

During all other regimes when more burners were operating on fuel oil, PM concentration was increasing. For the regime 4, PM emissions are higher than ELV2. It is possible to explain an increase in PM emissions as direct consequence of the higher sulphur content in fuel oil during combustion process. Since the natural gas is dominant fuel in the regime 4, ELV is represented as ELV2 defined for gas fuel furnace and it is $5 \mathrm{mg} / \mathrm{Nm}^{3}$. ELV1 represents emission-level value for liquid fuel furnace, and it is $100 \mathrm{mg} / \mathrm{Nm}^{3}$ (Official Gazette of the Republic of Serbia, No 30/97 and 35/97 1997). In all other regimes (1-3) when fuel oil was dominant, PM emissions were significantly below ELV1. For the operating regime 4, the emission of PM is higher than proposed ELV, and it is necessary to provide an emission reduction. Particular matter emission has exceeded the ELV, for regime 4, where sulphur content was $1.94 \%$; the recommendations are using fuel oil with lower sulphur content or fuel alternation.

Taking a look at Fig. 5, it is seen that when less fuel oil burners are operating (regime 4-5), an increase in NOx concentration occurs in the flue gas. Even when all eight burners were operating on natural gas, NOx concentration was around 4.47 times higher than ELV.

In addition, in case when all eight burners were operating on fuel oil, NOx concentration was around 2.53 times higher than ELV. Expected outcome of this experiment in CHP Zrenjanin was to try to prove that total switch from fuel oil to natural gas will decrease the NOx concentration below ELV, but this goal was not reached. 
Unexpected from the theory, switching from the regimes from 1 to 3 , where fuel oil was dominant, to the regimes 4 and 5 where natural gas was dominated, measurement data for NOx emissions were increasing instead to decrease. The solution could be reached by two approaches. The first one is to analyse the possibility to fix the problem of NOx reduction by pre-in-post-combustion process control, and/or to reconsider possibility that measurement was not properly done in the part of NOx emissions. Additional doubt regarding the measurements certainty is given by the fact that measured $\mathrm{O}_{2}$ concentration for 1 and 2 regimes in December 2007 was $16.3 \%$ that is less possible. There is an assumption that seal between measurement sonde and nozzle was not proper, and it was causing the fresh air leakage on flue gasses duct intake, which probably affected sampling process to be possible irregular.

In any case the fact is that NOx emission was detected and was higher than ELV. Even there is doubt about measurement data accuracy that was done by Accredited lab after the requirement that was submitted by the Inspection body, the fact is that CHP has problem regarding NOx emissions that should be solved (see Fig. 5). It should be mentioned that NOx emission level was also registered, during internal control that was provided as an annual control emission measurement, and that NOx reduction should be carried out.

The most influential parameters (Dvorak et al. 2010) for the NOx formation are fuel nitrogen concentration, peak temperature, oxygen concentration, time of exposure at peak temperature. The oxygen concentration parameter in CHP is controlled by the energy efficiency and minimum $\mathrm{CO}$ emission criteria. Time of exposure at peak temperature is constant during all working regimes, based on the boiler load. Combustion air temperature varies for all working regimes from 260 to $270{ }^{\circ} \mathrm{C}$ depending on the boiler load. Peak temperature is higher for fuel oil than for natural gas, and under these conditions should be noticed that level of NOx emissions is higher during fuel oil than natural gas combustion. Chemically bound nitrogen in the fuel is much higher in fuel oil than in natural gas and under the same combustion conditions that leads to forming higher level of NOx emissions.

Since the measurement data shows differently, it gives the picture that NOx measurements should be considered as a possible error and checked again, as well as to reconsider the optimization of the combined heat-power process and control as a possible solution, and in accordance with that to provide at least an overhaul of the boiler if it is necessary. Optimization should be taken with full respect of energy, economy and environmental aspects of the heat-power production.

Applied and recommended measures

Measures, proposed by theory as a consequence of practice, for reducing and controlling pollutant emissions, can be categorized as measures taken in pre-post-combustion process. Focusing on the problems that were occurred in above-mentioned experiment, emission reduction for two pollutants (PM and NOx) should be discussed.

In general, PM emissions depend on the completeness of combustion as well as on the oil ash content. PM emissions from residual oil burning are related to the oil sulphur content. This is because low-sulphur oil, either from naturally low-sulphur crude oil or desulphurized by one of several processes, exhibits substantially lower viscosity and reduced asphaltene, ash, and sulphur contents, which results in better atomization and more complete combustion (EPA 1995a, b).

Particulate matter emissions are usually a result of emitted fly ash with carbon component. The possible techniques for PM removal from flue gas, for large systems, can be divided into two groups, pre-combustion and postcombustion. During pre-combustion process, fuel re-filtration could be applied, as well as, a fuel substitution or fuel alteration (mixing the fuel with water and an emulsifying agent) may be used to reduce PM emissions. In the postcombustion controls of PM emissions mechanical collectors, electrostatic precipitators, fabric filters, etc, could be used (EPA 1995a, b).

Possible measures for reducing and controlling NOx emissions correspond in three categories (Dvorak et al. 2010). Measures taken in the pre-combustion process are additives, oxidizer switching, fuel switch or fuel alternation, combustion process intervention (that will be in further discussion as possible solution for our case) and postcombustion methods that include selective non-catalytic reduction (SNCR) and selective catalytic reduction (SCR). These controls can be used separately, or combined to achieve greater NOx reduction (EPA 1995a, b; Poullikkas 2004).

In-combustion process controls are the most widely used method of controlling NOx formation in all types of boilers and include low excess air, burners out of service, biasedburner firing, flue gas recirculation, overfire air, and lowNOx burners. Operating at low excess air involves reducing the amount of combustion air to the lowest possible level while maintaining efficient and environmentally compliant boiler operation. Burners out of service involve withholding fuel flow to all or part of the top row of 
burners so that only air is allowed to pass through. Biasedburner firing involves firing the lower rows of burners more fuel-rich than the upper row of burners. These methods may change the normal operation of the boiler and the effectiveness is boiler-specific. Implementation of these techniques may also reduce operational flexibility; however, they may reduce NOx by 10 to $20 \%$ from uncontrolled levels. Flue gas recirculation involves extracting a portion of the flue gas from the economizer section or air heater outlet and readmitting it to the furnace through the furnace hopper, the burner windbox, or both. Overfire air is a technique in which a percentage of the total combustion air is diverted from the burners and injected through ports above the top burner level. Low-NOx burners have been used as a retrofit NOx control for existing boilers and can achieve approximately 35 to $55 \%$ reduction from uncontrolled levels (EPA 1995a, b; Warnatz et al. 2006).

\section{Conclusion}

The aim of this paper was to provide flue gas emission data analysis, as well as to recommend measures for NOx and $\mathrm{PM}$ emission reduction according to the consideration that CHP Zrenjanin can affect supplied fuel oil quality (sulphur content in fuel oil) and was not able to perform significant fuel preparation using expensive additives or to build a flue gas treatment facility. The recommended measures have to be taken in combustion and in pre-combustion process, respectively.

According to the data analysis provided for NOx, it is seen there is an inconsistency between theoretical and measurement's expected results. It should be considered to repeat measurements and/or to provide combustion process control based on detailed analysis and optimization of the thermalpower plant. In any case, since NOx emissions are registered to be higher than proposed ELV, NOx reduction has to be carried out, and according to the real situation of CHP, it is recommended to provide in-combustion NOx reduction.

Potential solution in the case of CHP ZR from the PM reduction point of view is to operate on four fuel oil burners at least that would make fuel oil a dominant fuel, and according to the Regulation act, CHP ZR does not exceed that given ELV for fuel oil that is a higher value than ELV for natural gas. In large systems, the first possible intervention for PM is to provide preventive measure, i.e. fuel preparation. The second one is post-combustion process for PM emission reduction. In our case, fuel oil filtration is provided on regularly bases, but it should be considered to be applied an additional filtration of fuel oil.

Because PM level is not so high, it is not beneficial to invest in electro-filters, and even it is not recommended for large systems to reduce PM in combustion process, but since it is recommended for NOx reduction, it should reconsider a possibility to optimize combustion process to reduce NOx and PM emissions at the same time. For certain recommendation of the in-combustion process NOx reduction method that should be used, as well as PM reduction, it is necessary to provide more detailed analysis and optimization of the CHP.

In order to improve the optimization of combustion process and combined heat and power production in total, it is necessary to install the system for continuous $\mathrm{CO}$ and $\mathrm{O}_{2}$ concentration measurements into flue gasses duct, before regenerative air heat exchanger, and $\mathrm{O}_{2}$ concentration measurement, after regenerative air heat exchanger.

According to the principles of the environmental protection based on the continuous pollutant emissions monitoring, it is necessary to install the continuous emissions monitoring system (CEMS) into the stack.

It is necessary to reconsider the definition for ELV in the Regulation act, since in this case, it is a mixture of fuels that is utilized in CHP. Appropriate analysis and optimization based on energy, economy and environmental criteria of the thermal-power plant could give an answer how to define an appropriate ELV at the national level for every pollutant.

In general, taking into account the fact that CHP Zrenjanin is operating in certain technical and economic conditions and it is facing with a problem of two pollutant emissions exceeding the ELV, it is recommended to provide analysis and optimization of the CHP based on energy, economy and environmental aspects. It is also recommended to optimize an inspection/monitoring plan and maintenance programme based on risk assessment. In this case, it is necessary to provide at least an environmental, if not safety, health and economic risk assessment and to propose an effective inspection and maintenance plan.

Acknowledgments This paper is partly financed within III-42006, III-42004, III-46009 and No. 69-00-102/210-02 Projects of the Ministry of Education and Science of Republic of Serbia.

\section{References}

Ahern J (1980) The energy method of energy systems analysis. John Wiley, New York, NY

Azzarone F, Sciubba E (1995) Analysis of the energetic and exergetic sustainability of complex systems. Proc ASME Conf AES 35:161-174

Bahadori A, Vuthaluru H (2010) Estimation of energy conservation benefits in excess air controlled gas-fired systems. Fuel Process Technol 91:1198-1203

Bio-Ecological Centre (2008) Report on the emissions measurements results of harmful and hazardous substances in Power Industry (2008), "Pannonia Thermal Power Plants, Novi Sad", Thermal Power Plant Zrenjanin, The new plant section (boiler B1), Zrenjanin, 04.01.2008 and 05.03.2008 
Bogdan Ž, Kopjar D (2006) Improvement of the cogeneration plant economy by using heat accumulator. Energy 31(13):2285-2292

Bogdan Ž, Cehil M, Kopjar D (2007) Power system optimization. Energy 32(6):955-960

Borelli SJS, Oliveira JS (2008) Exergy based method for analysing the composition of the electricity cost generated in gas-fired combined cycle plants. Energy 33:153-162

Cardu M, Baica M (2005) Regarding the relation between the NOx content and $\mathrm{CO}$ content in thermo power plants flue gases. Energy Convers Manag 46:47-59

Chicco G, Mancarella P (2008) Assessment of the greenhouse gas emissions from cogeneration and trigeneration systems. Part I: models and indicators. Energy 33:410-417

Dimitroulopoulou C, Plemmenos V, Kyrios T, Ziomas IC (2011) Air pollution exposure indicator for Greece. Atmos Environ 45:2138-2144

Dvorak R, Chlapek P, Jecha D, Puchyr R, Stehlık P (2010) New approach to common removal of dioxins and NOx as a contribution to environmental protection. J Clean Prod $18: 881-888$

Elbir T, Muezzinoglu A, Bayram A (2000) Evaluation of some air pollution indicators in Turkey. Environ Int 26:5-10

England GC, McGrath TP, Gilmer L, Seebold JG, Lev-On M, Hunt T (2001) Hazardous air pollutant emissions from gas-fired combustion sources: emissions and the effects of design and fuel type. Chemosphere 42:745-764

Envirolab (2006) Tecora isostack basic. Available at: http://www. envirolab.rs/en/isostack-basic-isokinetic-sampler

EPA (1995a) Compilation of air pollutant emission factors, 5th edn, vol i, chapter 1: external combustion sources, fuel oil combustion. Available at: http://www.epa.gov/ttn/chief/ap42/ch01/final/ c01s03.pdf

EPA (1995b) Compilation of air pollutant emission factors, 5th edn, vol i, chapter 1: external combustion sources, natural gas combustion. Available at: http://www.epa.gov/ttn/chief/ap42/ ch01/final/c01s04.pdf

European Commission (2011) EC directives on stationary source emissions. Available at: http://ec.europa.eu/environment/air/ legis.htm

Fang Q, Wang H, Wei Y, Lei L, Duan X, Zhou H (2010) Numerical simulations of the slagging characteristics in a down-fired, pulverized-coal boiler furnace. Fuel Process Technol 91:88-96

Frangopoulos CA (1990) Intelligent functional approach: a method for analysis and optimal synthesis-design-operation of complex systems. In: Stecco SS, Moran MJ (eds) A future for energy. Pergamon Press, Oxford, pp 805-815

Hewlett Packard (2006) UV/VIS spectrophotometer, model 8452A. Available at: http://www.gmi-inc.com/agilent-hp-8452a-diodearray-spectrophotometer.html

Hossain KA, Khan F, Hawboldt K (2010) SusDesign—an approach for a sustainable process system design and its application to a thermal power plant. Appl Therm Eng 30:1896-1913

Kaewboonsonga W, Kuprianov VI, Chovichien N (2006) Minimizing fuel and environmental costs for a variable-load power plant (co-)firing fuel oil and natural gas: Part 1. Modeling of gaseous emissions from boiler units. Fuel Process Technol 87:1085-1094

Kermes V, Belohradský P, Oral J, Stehlík P (2008) Testing of gas and liquid fuel burners for power and process industries. Energy 33(10):1551-1561

Kuprianov VI, Kaewboonsong W (2004) Modeling the effects of operating conditions on fuel and environmental costs for a 310 MW boiler firing fuel oil. Energy Convers Manag 45: $1-14$
Kuprianova VI, Kaewboonsong W, Douglas PL (2008) Minimizing fuel and environmental costs for a variable-load power plant (co)firing fuel oil and natural gas, Part 2. Optimization of load dispatch. Fuel Process Technol 89:55-61

Kyoto Protocol to the United Nations Framework Convention on Climate Change (1998) United Nation. Available at: http:// unfccc.int/kyoto_protocol/items/2830.php

Law on Environmental Protection (2004) Official Gazette of the Republic of Serbia, no. 135/04. Available at: http://www.bcif. org/docs/zak/Zakon_o_zastiti_zivotne_sredine.pdf

Li H, Marechal F, Favrat D (2010) Power and cogeneration technology environomic performance typification in the context of $\mathrm{CO}_{2}$ abatement part II: combined heat and power cogeneration. Energy 35(9):3517-3523

Lin L, Tsatsaronis G (1993) Cost optimization of an advanced IGCC power plant concept design. In: Richter HJ (ed) Thermodynamics and the design, analysis and improvement of energy systems, AES vol 10. ASME, NY, p 156-166

Nakomcic B (2008), Integral approach to the optimization of thermalprocess plants based on the thermoeconomic, environmental and cost-benefit analysis and risk management, Ph.D. dissertation. Faculty of Techical Sciences, Novi Sad, Serbia

Nakomcic B, Basic DJ, Ciupinski L, Manaj W, Kurzydlowski KJ (2006) Non-destructive testing applied for risk reduction in petrochemical installations, ECOS 2006 19th conference on efficiency, cost, optimization, simulation and environmental impact of energy systems, Crete, Greece, vol 2, p 767-774

Nazari S, Shahhoseini O, Sohrabi-Kashani A, Davari S, Paydar R, Delavar-Moghadam Z (2010) Experimental determination and analysis of $\mathrm{CO}_{2}, \mathrm{SO}_{2}$ and $\mathrm{NOx}$ emission factors in Iran's thermal power plants. Energy 35:2992-2998

Official Gazette of the Republic of Serbia, No 30/97 and 35/97 (1997) Regulation on emission's limiting values, methods and terms of data measuring and tracking. Available at: http://www.google.com/ url $? \mathrm{sa}=\mathrm{t} \&$ source $=$ web $\& \mathrm{~cd}=1 \&$ ved $=0 \mathrm{CBMQFjAA} \&$ url $=\mathrm{http} \%$ $3 \mathrm{~A} \% 2 \mathrm{~F} \% 2 \mathrm{Fekologija.pf}$.uns.ac.rs\%2FVazduh\%2FPravilnik $\%$ 25202. doc\&rct=j\&q=pravilnik $\% 200 \% 20$ nacinu $\% 20 \mathrm{i} \% 20$ rokovima\% 20merenja\%20emisije\&ei=S9Z4TZXkNM7FswbAxLzvBw\&usg= AFQjCNGYs1PbUjiv3HmurPB6a5x3CFHT9A\&cad=rja

Ozdemir E (2004) Energy conservation opportunities with a variable speed controller in a boiler house. Appl Therm Eng 24:981-993

Poullikkas A (2004) Cost-benefit analysis for the use of additives in heavy fuel oil fired boilers, Elsevier. Energy Convers Manag 45:1725-1734

Pro-Ekos doo (2006) AT-801X2. Available at: http://www.proekos. com/documents/at801x2.pdf

Schneider D, Bogdan Ž (2007) Effect of heavy fuel oil/natural gas cocombustion on pollutant generation in retrofitted power plant. Appl Therm Eng 27(11-12):1944-1950

Taubman EI (1983) Analysis and synthesis of thermal systems. Energoatomizdat, Moscow

Testo Inc. (2006) Short operation instruction manual of Testo 350M/ XL flue gas analyzer. Testo Inc., Flanders, Germany. Available at: http://www.gastech.com.au/files/manuals/Testo-350.pdf

Spakovsky VMR, Frangopoulos CA (1993) A global environomic approach for energy systems analysis and optimization, Part II, ENSEC'93. Cracow, Poland, pp 133-144

Tsatsaronis G, Winhold M (1984) Thermoeconomic analysis of power plants, EPRI AP-3651, RP 2029-8. Final report. Electric Power Research Institute, Palo Alto, CA

Vallero DA (2008) The measurement and monitoring of air pollution. In: Vallero DA (ed) Fundamentals of air pollution, 4th edn. Elsevier, Amsterdam, pp 457-537 
Wang LK, Pereira NC, Hung Y (2005) Advanced air and noise pollution control. Humana Press Inc., New Jersey

Warnatz J, Maas U, Dibble RW (2006) Formation of nitric oxides. In: Warnatz J, Maas U, Dibble RW (eds) Combustion, physical and chemical fundamentals, modelling and simulation, experiments, pollutant formation, 4th edn. Springer, New York, pp 259-276
Xu X, Song C, Miller BG, Scaroni AW (2005) Adsorption separation of carbon dioxide from flue gas of natural gas-fired boiler by a novel nanoporous "molecular basket" adsorbent. Fuel Process Technol 86:1457-1472 